A. Yanko, I. Fil

National University «Yuri Kondratyuk Poltava Polytechnic», Poltava, Ukraine

\title{
THE TASK OF CHOOSING A RELIABLE PATH FOR MESSAGE TRANSMISSION IN A COMPUTER NETWORK
}

\begin{abstract}
The article provides a calculation and comparative analysis of the reliability and productivity of computer systems in a positional binary number system and in a non-positional number system in residual classes (residual number system - RNS), for calculations and comparative we consider practical task. The main goal is to solve the task of choosing a reliable path for message transmission in a computer network. Calculation and comparative evaluation of the reliability and performance of the computer system in the RNS and the existing in the positional binary number system computer system APO-221 of the product 15E1235 (automatic message switching center - ASC) when solving the basic task of the ASC the task of choosing the transmission path of a formalized message (path selection algorithm (PSA)).
\end{abstract}

Keywords: automatic switching center, computer system, computer systems and components of fast processing of integer data, data transmission systems, path selection algorithm, positional number systems.

\section{Introduction}

The increasing requirements for modern computer systems and components of fast processing of integer data (CSCPID) necessitate the constant search, development and implementation of methods for fast data processing. It should be noted that, despite the intensive development of modern information technologies used to create hardware and software tools of CSCPIDs, there are still many unsolved scientific and technical problems and problems in this area. First of all, this is due to the following circumstances:

- high requirements, at the same time, as to the performance of data processing, and to the reliability of the operation of CSCPIDs, operating in real time;

- the limited capabilities of modern CSCPIDs to carry out in real time simultaneously highly reliable and high-speed parallel implementation of the computational process.

Meeting the above requirements and eliminating these shortcomings is difficult on the basis of wellknown, developed and tested methods of data processing based on the use of binary positional number systems (PNS) [1].

Analysis of literature. The first in the USSR who drew attention to a new machine arithmetic called residual number system (RNS) was Fedor Viktorovich Lukin at the end of the 50s. Vilzhan Mavlyutinovich Amerbayev, a doctor of technical sciences, professor, academician of the National Academy of Sciences of Kazakhstan, one of the leading theorists in the field of RNS, and active participants in its practical application said: "Israel Yakovlevich Akushsky told me that he received the first information on the RNS from F. V. Lukin as a closed report of work in the United States. According to Israel Yakovlevich, Fyodor Viktorovich considered RNS to be a very promising direction in the development of computing technology." His subsequent actions confirm this - it was precisely through the efforts of $F$. $\mathrm{V}$. Lukin that the system of residual classes received such rapid and successful development in the country, and his departure from life coincides with the beginning of the decline in its development [2]. Comparing fragmentary information from different sources, it is possi- ble to reconstruct this story as follows. The first thought about the possibility of using RNS in computing technology in 1955 in a brief article was expressed by the Czechoslovak engineer M. Valah, he was actively supported by the mathematician A. Svoboda. They became the pioneers of RNS. The Americans became interested in their work, and close cooperation ensued, as a result of which, a few years later, Svoboda and Valakh moved to the USA, where work on the system of residual classes was expanded on a broad front [1].

\section{Main material}

In existing data transmission systems (DTS) there is a computer system (CS) in the control loop. The result of the analysis of the operation of technical systems and real-time information processing tools showed that in most cases the efficiency of using the entire DTS as a whole depends on the performance of the data processing of the CS. Obviously, one of the most important characteristics of specialized CS is its performance. CS performance is determined by the amount of computing work per unit of time.

To conduct a comparative assessment, we calculate the performance of the CS in the RNS and the existing in the PNS CS APO-221 of the product 15E1235 automatic message switching system. In turn, the product $15 \mathrm{E} 1235$ is part of the $15 \mathrm{E} 1142$ system, an automatic switching center (ASC), which performs the function of automated exchange of control information between data sources and consumers located at command posts, headquarters, and other special-purpose facilities. The main, basic task of the message switching process is the task of choosing the transmission path of a formalized message (path selection algorithm (PSA)). In the future, by the standard task we will understand the task of implementing PSAs. We will determine the CS performance when solving the standard task of implementing PSAs between two CS subscribers.

Let us conduct a quantitative assessment of the productivity $\Pi$ of the CS APO-221. In this case, by productivity $\Pi$ we mean the number of standard PSA tasks per unit time in normal operation, i.e.:

$$
\Pi=1 / T_{S}
$$


where $T_{s}=T_{\text {in }}\left(1-\varepsilon_{1}\right)+T_{\text {solv }}+T_{\text {ex }}+T_{c}+T_{\text {maint }}+T_{\text {out }}\left(1-\varepsilon_{2}\right)-$ PSA standard problem solving time; $\mathrm{T}_{\text {in }}$ - input time; $\mathrm{T}_{\text {solv }}$ - direct problem solving time; $\mathrm{T}_{\mathrm{ex}}$ - time spent exchanging information with RAM; $T_{c}$ - the time of monitoring the functioning of the CSCPID using tests conducted in the process of solving the problem; $\mathrm{T}_{\text {maint }}$ time spent on preventive maintenance, troubleshooting and troubleshooting, reduced to a single solution to the problem; $\mathrm{T}_{\text {out }}$ - output time; $\varepsilon_{1}, \varepsilon_{2}$ - the coefficients of combining, respectively, input and output information with the process of solving the problem $\left(\varepsilon_{1}, \varepsilon_{2} \leq 1\right)$.

Note that for a CS in a RNS, the time $T_{i n . R N S}$ of inputting the initial information and the time $T_{\text {out.RNS }}$ of outputting the results of solving the problem are determined by the corresponding expressions

$$
T_{\text {in.RNS }}=T_{\text {in }}+T_{\text {conv } 1}, T_{\text {out } . R N S}=T_{\text {out }}+T_{\text {conv } 2},
$$

where $T_{\text {conv } 1}$ - operands conversion time from PNS to RNS, $T_{\text {conv2 }}$ - operands conversion time from RNS to PNS. In this case, the input / output time of information for the CS in the RNS is slightly longer than for PR-009 in the PNS due to the need to convert the operands from the PNS to the RNS and vice versa. The research results showed that the following condition is fulfilled for the tabular principle of data processing: $T_{\text {conv } 1}+T_{\text {conv } 2} \leq 1$, in relative temporary arbitrary units (conventional units). This circumstance was subsequently taken into account when determining the time for the implementation of PSAs in RNS. Specialized CS APO-221 of the product $15 \mathrm{E} 1235$ of the system $15 \mathrm{E} 1142$ consists of two processors PR-009, as well as from the command memory, data memory and input-output channel. The PR-009 processor implements a set of instructions (arithmetic, logical, transition, exchange, etc.) through four-byte $(1=4)$ bit words. To improve the speed of solving the problem in PR-009, a combination mode is used, in which the selection of the next command from the command memory begins until the previous command is completed. In the product $15 \mathrm{E} 1235$, it is assumed that $\varepsilon_{1}=\varepsilon_{2}=0,2$.

The main time characteristics in arbitrary units of the product 15E1235 and PR-009 of the system $15 \mathrm{E} 1142$ are given in table 1.
Computing system CS APO-221 was created according to the reliable scheme of hot standby. If both PR-009 processors are operational, then the processing of current information is provided by one processor ("master"), and the second ("slave") is a hot reserve. The assignment of the processor to the "master" is carried out by software. Failure in the first and second PR009 leads to the failure of the product $15 \mathrm{E} 1235$ and the system $15 \mathrm{E} 1142$ as a whole [3].

The process of functioning of the product 15E1235 is provided by software and hardware. The main mode of operation of this product is message switching. The task of PSAs belongs to the class of modern decentralized and adaptive control algorithms solved by means of CS DTS. Table 2 shows: the stages of PSA implementation, the set of operations that implements this stage of PSA calculations, as well as the frequency of implementation of standard operations in PR-009. Briefly describe the implemented PSA. The essence of the PSA is to determine the optimal way to bring the message from the source of information to the data consumer in the specialized system 15E599 of the DTS information and settlement system "Yarus". Information for solving the PSA algorithm is stored in the $15 \mathrm{E} 1142$ system in a matrix M consisting of two adjacency matrices: telephone and telegraph. When choosing a path, binary operations on integer numbers of rows of these matrices are used [4-7].

The number of rows and columns in these matrices is equal to the number of ASCs. The PSA algorithm consists of four main branches: transmission of a message along the route; path selection using the matrix $\mathrm{M}_{\mathrm{f}}$ (telephone network); path selection using the $\mathrm{M}_{\mathrm{g}}$ matrix (telegraph network); sending a message to the operator. If the value of the transmission variant corresponds to the transmission variant along the route, the first branch is connected.

The choice of the way when the PSA operates on the second and third branches is based on global information on the structure of the telecommunication network and local information on the queues and network load. For a given ASC, for each message, the path is selected sequentially, starting with the shortest paths, thereby determining the set $U_{s}$ of transit ASCs on the path to the desired ASC of the recipient with a deviation $S$ from the shortest path.

Table 1-Main characteristics of the product $15 \mathrm{E} 1142$

\begin{tabular}{|c|c|c|c|}
\hline No. & Product, syst. (unit) & Type of operation & Time [conv. units] \\
\hline \multirow{2}{*}{1} & RAM-094 & Access cycle & 3 \\
\cline { 2 - 4 } & (RAM-095) & Sampling time & 0,6 \\
\hline 2 & ROM-098 & Access cycle & 3 \\
\hline \multirow{3}{*}{3} & \multirow{3}{*}{ PR-009 } & Information I O time & 1 \\
\cline { 3 - 4 } & & Test time & 7 \\
\cline { 3 - 4 } & & Average time of addition (subtraction) operation in combination mode & 20 \\
\cline { 3 - 4 } & & Average runtime of an addition (subtraction) operation in normal mode & 200 \\
\cline { 3 - 4 } & \multirow{2}{*}{4} & Aime spent on preventive maintenance, troubleshooting, and elimination, & 0,5 hours \\
\hline \multirow{2}{*}{5} & \multirow{2}{*}{$15 \mathrm{E} 1235$} & resulting in a one-time solution to the PSA problem & $256 \mathrm{kbyte}$ \\
\hline 6 & \multirow{2}{*}{$15 \mathrm{E} 1235$} & Command memory capacity & $192 \mathrm{kbyte}$ \\
\hline 7 & $15 \mathrm{E} 1235$ & Data memory capacity & $0,1,2,3$ \\
\hline \multirow{2}{*}{8} & $115 \mathrm{E} 1235$ & Command Format System & 32 bits \\
\cline { 3 - 4 } & \multirow{2}{*}{$15 \ni 1142$} & Bit grid & 0,9995 \\
\hline
\end{tabular}


Table 2- The list of implemented functions, type and number of operations included in the algorithm for choosing a message path

\begin{tabular}{|c|c|c|c|}
\hline No. & $\begin{array}{l}\text { Implemented } \\
\text { function }\end{array}$ & $\begin{array}{c}\text { Function } \\
\text { type }\end{array}$ & $\begin{array}{l}\text { Number } \\
\text { of ope- } \\
\text { rations }\end{array}$ \\
\hline \multirow[b]{2}{*}{1} & \multirow{2}{*}{$\begin{array}{l}\text { Determining the values of the } \\
\text { elements } \mathrm{a}_{\mathrm{jif}}\left(\mathrm{a}_{\mathrm{jig}}\right) \text { rows (col- } \\
\text { umns) of the adjacency ma- } \\
\text { trix. }\end{array}$} & ROM access & 40 \\
\hline & & Addition & 30 \\
\hline 2 & $\begin{array}{l}\text { Formation of a binary string } \\
\text { of accessibility. }\end{array}$ & $\begin{array}{l}\text { Addition } \\
\text { mod. } 2\end{array}$ & 40 \\
\hline \multirow{2}{*}{3} & \multirow{2}{*}{$\begin{array}{l}\text { The definition of an adjacent } \\
\text { branch. }\end{array}$} & Addition & 4 \\
\hline & & Comparison & 3 \\
\hline \multirow[b]{2}{*}{4} & \multirow{2}{*}{$\begin{array}{l}\text { Definition of transit ASC set } \\
\qquad U_{s}\end{array}$} & Addition & 30 \\
\hline & & $\begin{array}{l}\text { Addition } \\
\text { mod. } 2\end{array}$ & 20 \\
\hline \multirow[b]{2}{*}{5} & \multirow{2}{*}{$\begin{array}{l}\text { Determination of the neces- } \\
\text { sary direction of information } \\
\text { transfer. }\end{array}$} & Addition & 100 \\
\hline & & Comparison & 50 \\
\hline 6 & Route $\mathrm{q}_{\mathrm{i}+1}=\mathrm{q}_{\mathrm{i}}+\mathrm{S}$ flagging. & Addition & 50 \\
\hline \multirow{4}{*}{7} & \multirow{4}{*}{$\begin{array}{l}\text { Determining the priority of } \\
\text { the message (calculation of } \\
\text { the function } T_{x} \text { ). }\end{array}$} & Addition & 400 \\
\hline & & Multiplication & 1600 \\
\hline & & RAM access & 10 \\
\hline & & Comparison & 10 \\
\hline \multirow{4}{*}{8} & \multirow{4}{*}{$\begin{array}{l}\text { Calculation of algorithms for } \\
\text { the formation, transmission } \\
\text { and processing of service } \\
\text { information on the status of } \\
\text { the telecommunications } \\
\text { network. }\end{array}$} & RAM access & 100 \\
\hline & & ROM access & 20 \\
\hline & & Addition & 200 \\
\hline & & Subtraction & 300 \\
\hline \multirow{3}{*}{9} & \multirow{3}{*}{ Reproduction of messages. } & RAM access & 250 \\
\hline & & ROM access & 40 \\
\hline & & Addition & 200 \\
\hline 10 & $\begin{array}{c}\text { Delivering information } \\
\text { through communication } \\
\text { channels. }\end{array}$ & - & - \\
\hline
\end{tabular}

For the further transmission, a ASC is selected as the candidate's ASC for the further transmission, the transmission direction to which at the moment has the minimum quoted queue length $L_{s}=l+l_{s}+l \delta_{s}$, where $l$ is the queue length, counted in messages for 1 communication direction channel.

At each step, according to $\mathrm{S}$ on the admissibility of deviations from the shortest path, the telephone direction is first checked. If it is unacceptable, then the telegraphic direction is checked.

After determining the direction of further transmission, the priority of message transmission is determined. For this, the function of estimating the time of bringing the message is calculated as $T_{x}=\tau \sigma_{1} d+\sigma_{2}\left(l+l_{\delta s}\right)$, where $d$ is the length of the residual path (in arcs) to the recipient's ASC; $\sigma_{1}, \sigma_{2}$ - constants selected from ROM-098. Next, using the CS, the process of calculating the algorithms for the formation, transmission and processing of service information about the state of the telecommunication network is carried out. To bring information to all ASCs, the message is propagated to the higher links 1, 2 and 3 of the DTS allocated by ASC.

Further, through the communication channels, the process of bringing information to the ASCs corresponding to the levels (links) of the DTS is carried out.
Based on the data presented in tables 1 and 2, we will create table 3 . This table contains general information about the number of operations of each type included in the PSA. Table 3 also contains calculated data on the total implementation time of all operations of each type in the PNS contained in the PSA for four-byte $(32$ binary bits $(1=4))$ bit words.

Based on the data in table 3, in accordance with the expression (1), we determine the performance values $\Pi_{P N S}$ of the product $15 \mathrm{E} 1235$ when solving the PSA algorithm in the PNS. Using the results of calculations placed in table 3 , we determine the time to solve the PSA problem $\mathrm{T}_{\text {solv }}$. We get that $\mathrm{T}_{\text {solv }}=0,33 * 10^{4}$ conv. units. Given that $\varepsilon_{1}=\varepsilon_{2}=0,2$, we define the following values: $T_{\text {in }}\left(1-\varepsilon_{1}\right) \approx T_{\text {out }}\left(1-\varepsilon_{2}\right)=1,2$ conv. units; $\mathrm{T}_{\mathrm{ex}}=1380$ conv. units; $\mathrm{T}_{\mathrm{c}}=1$ conv. units; $\mathrm{T}_{\text {maint }}=0,5$ conv. units. $\mathrm{n}$ accordance with the expression (1), we determine the value of the productivity of the product 15E1235 when solving the PSA algorithm.

The calculation results showed that $\Pi_{P N S} \approx 3$ PSA / conv.units, i.e. the user productivity of the CS processor in the PNS is equal to three PSA reference tasks, one relative conventional unit of time.

In order to assess the performance of CS in RNS, we will use the previously obtained research results. To do this, it is necessary to determine the set of conversion coefficients of the relative time for the implementation of arithmetic operations, implemented on the basis of the tabular principle (TP) [8], respectively, for the addition $\mathrm{K}^{+}$, subtraction $\mathrm{K}^{-}$и comparison $\mathrm{K}^{\text {comp. }}$ of numbers for $1=4$. From the table 3 we have that $\mathrm{K}^{+}=2 / 63=0,03, \mathrm{~K}$ $=2 / 2048=0,001$ and $K^{\text {comp. }}=7 / 63=0,1$. Based on the obtained values of conversion factors, we determine the values of the total implementation time of all operations of each type. Table 4 summarizes the number of operations of each type included in the PSA and also the estimated data on the total implementation time of all operations of each type in the RNS contained in the PSA for four-byte (32 binary bits $(1=4))$ bit words.

\section{Table 3-PSA characteristics in PNS}

\begin{tabular}{|c|c|c|c|}
\hline $\begin{array}{c}\text { Item } \\
\text { No. }\end{array}$ & $\begin{array}{c}\text { Type of } \\
\text { operation }\end{array}$ & $\begin{array}{c}\text { Number of } \\
\text { operations }\end{array}$ & $\begin{array}{c}\text { Operation execu- } \\
\text { tion time [conv. } \\
\text { units] }\end{array}$ \\
\hline 1 & RAM access & 360 & 1080 \\
\hline 2 & ROM access & 100 & 300 \\
\hline 3 & Addition & 1314 & 9198 \\
\hline 4 & Multiplication & 1600 & 320000 \\
\hline 5 & Comparison & 63 & 441 \\
\hline
\end{tabular}

Table 4-PSA characteristics in RNS

\begin{tabular}{|c|c|c|c|}
\hline $\begin{array}{c}\text { Item } \\
\text { No. }\end{array}$ & $\begin{array}{c}\text { Type of } \\
\text { operation }\end{array}$ & $\begin{array}{c}\text { Number of } \\
\text { operations }\end{array}$ & $\begin{array}{c}\text { Operation execu- } \\
\text { tion time [conv. } \\
\text { units] }\end{array}$ \\
\hline 1 & RAM access & 360 & 1080 \\
\hline 2 & ROM access & 100 & 300 \\
\hline 3 & Addition & 1314 & 275 \\
\hline 4 & Multiplication & 1600 & 320 \\
\hline 5 & Comparison & 63 & 6 \\
\hline
\end{tabular}


Based on the relation (1), the performance of the $\mathrm{CS}$ in the RNS when solving the PSA was calculated. Analysis of the results showed that the performance of the CS in the RNS is equal to the value of $\prod_{R N S} \approx 500$ PSA / conv. units, i.e. the performance of the CS processor in the RNS is 500 PSA reference tasks for one conventional unit This is somewhere around 160 times larger than with PNS (see table 5).

Table 5-The value of some characteristics of the CS for various number systems

\begin{tabular}{|c|c|c|}
\hline \multirow[b]{2}{*}{ CS characteristics } & \multirow[b]{2}{*}{ PNS } & RNS \\
\hline & & $\begin{array}{c}\text { Tabular } \\
\text { principle }\end{array}$ \\
\hline $\begin{array}{c}\text { User productivity } \Pi[\mathrm{PSA} / \\
\text { conv.units] }\end{array}$ & 3 & 500 \\
\hline $\begin{array}{c}\text { Reliability } \mathrm{P}_{\mathrm{CSCPID}}\left(\mathrm{t}_{\mathrm{PSA}}\right) \\
\text { [probability of failure-free } \\
\text { operation] }\end{array}$ & 0,9660 & 0,9999 \\
\hline $\begin{array}{l}\text { The relative amount } \mathrm{V}_{\mathrm{CSCPID}} \\
\text { of equipment [conv. units] }\end{array}$ & 64 & 60 \\
\hline $\begin{array}{c}\text { The number } \Delta A \text { of addi- } \\
\text { tional input amount of } \\
\text { equipment }[\%]\end{array}$ & 100 & 87,5 \\
\hline
\end{tabular}

Table 5 further shows that using the tabular principle of data processing, as well as using well-known calculated data, the use of RNSs provides a higher reliability (in the probability of failure-free operation of the $\left.P_{\text {CSCPID }}\left(t_{P S A}\right)\right)$ of the CS than with the use of the tripled majority structure in binary PNS and with the smallest additionally entered amount of equipment.

\section{Conclusion}

In accordance with the goal, in the article, a calculation and comparative analysis of the performance of CS in PNS and in RNS was performed. As an example of calculation and comparative analysis of data processing performance, the basic task of the message switching process is given - the task of choosing the transmission path of a formalized message between subscribers of the CS. The research results showed that the use of RNS as a number system for CS allows, in comparison with PNS, to significantly increase the productivity of processing data presented in integer form. Thus, the TP implementation of the arithmetic operations that are part of the PSA, when compared with the binary PNS, allows to increase the performance of non-positional CS operating in the RNS by 160 times.

\title{
REFERENCES
}

1. Krasnobayev, V., Kuznetsov, A., Yanko,A, Koshman, S., Zamula, A., Kuznetsova, T. (2019), "Data processing in the system of residual classes. Monograph,” ASC Academic Publishing, 208 p. - ISBN: 978-0-9989826-6-3 (Hardback),

2. Akushskii, I.Ya. and Yuditskii, D.I. (1995), "Machine Arithmetic in Residual Classes," Sov. Radio, Moscow, 440 p.

3. Krasnobayev, V., Yanko, A. and Koshman, S. (2016), "A method for arithmetic comparison of data represented in a residue number system," Cybernetics and Systems Analysis, vol. 52, Issue 1, pp. 145-150.

4. Krasnobayev, Koshman, S. and Mavrina, M. (2014), "A method for increasing the reliability of verification of data represented in a residue number system," Cybernetics and Systems Analysis, vol. 50, Issue 6, pp. 969-976.

5. Зиков I. С., Кучук Н. Г., Шматков С. І. Синтез архітектури комп'ютерної системи управління транзакціями е-learning. Сучасні інформачійні системи. 2018. Т. 2, № 3. C. 60-66. DOI: https://doi.org/10.20998/2522-9052.2018.3.10

6. Nechausov A., Mamusuĉ I., Kuchuk N. Synthesis of the air pollution level control system on the basis of hyperconvergent infrastructures. Сучасні інформачійні системи. 2017. T. 1, № 2. C. 21-26. DOI: https://doi.org/10.20998/2522-9052.2017.2.04

7. Кучук Н.Г., Гавриленко С.Ю., Лукова-Чуйко Н.В., Собчук В.В. Перерозподіл інформаційних потоків у гіперконвенгертній системі / С.Ю. Гавриленко. Сучасні інформаційні системи. 2019. Т. 3, № 2. С. 116-121. DOI: https://doi.org/10.20998/2522-9052.2019.2.20

8. Kavun, S., Zamula, A. and Mikheev, I. (2017), "Calculation of expense for local computer networks," 2017 4th International Scientific-Practical Conference Problems of Infocommunications. Science and Technology (PIC S\&T), Kharkov, pp. 146151.

Received (Надійшла) 29.06.2020

Accepted for publication (Прийнята до друку) 02.09.2020

\section{Задача вибору надійного шляху для передачі повідомлень у комп'ютерній мережі}

\author{
А. С. Янко, І. В. Філь
}

Анотація. Актуальність дослідження. У існуючих системах передачі даних в контурі управління $\epsilon$ комп’ютерна система. Результати аналізу роботи технічних систем та засобів обробки інформації в режимі реального часу показали, що в більшості випадків ефективність використання всієї системи в цілому залежить від ефективності обробки даних. Очевидно, що однією з найважливіших характеристик спеціалізованої системи є іiї продуктивність, що визначається обсягом обчислювальної роботи за одиницю часу. Основна мета - вирішити задачу вибору надійного шляху передачі повідомлень у комп'ютерній мережі. Результати. У статті наведено розрахунок та порівняльний аналіз надійності та продуктивності обчислювальних систем в позиційній двійковій системі числення та в непозиційній системі числення в залишкових класах (система залишкових класів - СЗК), для розрахунків та порівняння ми розглядаємо практичну задачу. Розрахунок та порівняльна оцінка надійності та продуктивності обчислювальної системи в СЗК та існуючої в позиційній двійковій системі числення обчислювальної системи АПО-221 виробу 15Е1235 (центр автоматичної комутації повідомлень - ЦАК) при вирішенні основного завдання ЦАК - задача вибору шляху передачі формалізованого повідомлення (алгоритм вибору шляху). Висновок. Результати досліджень показали, що використання RNS як системи числення для CS дозволяе, порівняно з PNS, значно збільшити продуктивність обробки даних, представлених у цілочисельній формі. Таким чином, реалізація TР арифметичних операцій, які є частиною PSA, у порівнянні 3 двійковим PNS дозволяє збільшити продуктивність непозиційних CS, що працюють в RNS, у 160 разів.

Ключов і слов а: алгоритм вибору шляху, комп'ютерна система, комп'ютерні системи та компоненти швидкої обробки цілочисельних даних, позиційні системи числення, система залишкових класів, системи передачі даних. 